\title{
Water And Land Productivity of Lettuce (Lactuca sativa) Cultivation on Floating Pot in Wetland
}

\author{
Lily Endah Diansari ${ }^{1, *}$, Satyanto K. Saptomo ${ }^{2}$, Budi Indra Setiawan ${ }^{3}$ \\ ${ }^{1}$ Program Studi Teknik Sipil, Sekolah Tinggi Teknologi Pagar Alam \\ ${ }^{2}$ Departemen Teknik Sipil dan Lingkungan, Institut Pertanian Bogor \\ ${ }^{3}$ Departemen Teknik Sipil dan Lingkungan, Institut Pertanian Bogor \\ *Corresponding Author: diansarilily@gmail.com
}

\begin{tabular}{llll} 
Article history & & \\
\hline Received & Received in revised form & Accepted & Available online \\
13 July 2019 & 7 August 2019 & 30 August 2019 & 31 August 2019 \\
\hline
\end{tabular}

\begin{abstract}
The objective of this study was to determine the values of water and land productivity of floating pot cultivation in wetland and to find out the effectivity of floating pots usage for agriculture in wetlands. The planting media used were mineral soil added with $0 \%$ of soil having permeability $36.07 \mathrm{~cm} /$ hour, $30 \% 38.33 \mathrm{~cm} / \mathrm{hour}, 50 \%$ $51.23 \mathrm{~cm} /$ hour, $70 \% 69.60 \mathrm{~cm} /$ hour and $100 \%$ was not having permeability value. The water delivery used was legacy cloth which had $158.4 \mathrm{~cm} /$ hour of hydraulic conductivity value. The floating pots were placed in the experimental tank at greenhouse. Water level decrease in the experimental tank was total evapotranspiration for all plants in five planting media treatments. Water level reduction during the 41-days planting period was $40.56 \mathrm{~mm}$ with $0.081 \mathrm{~m}^{3}$ of total water volume. The productivity values of land and water in the $0 \%, 30 \%, 50 \%, 70 \%$ and $100 \%$ of peat treatments were $1.29,1.25,1.06,0.8$ and $0 \mathrm{~kg} / \mathrm{m}^{2}$ dan $1.63,1.63,1.38,1.04 \mathrm{dan} 0 \mathrm{~kg} / \mathrm{m}^{3}$, respectively. Keywords: floating pot, land productivity, sub-surface irrigation, water productivity
\end{abstract}

\begin{abstract}
Abstrak (Indonesian): Penelitian ini bertujuan untuk mengetahui nilai produktivitas air dan lahan pot terapung di lahan basah dan untuk mengetahui apakah pot terapung tersebut optimal atau tidak untuk pertanian di lahan basah. Media tanam yang digunakan adalah tanah mineral dicampur tanah gambut $0 \%, 30 \%, 50 \%$, 70\%, dan $100 \%$ yang masing-masing mempunyai nilai konduktivitas hidrolik kecuali yang $100 \%$ adalah $36.07 \mathrm{~cm} / \mathrm{jam}, 38.33$ $\mathrm{cm} / \mathrm{jam}, 51.23 \mathrm{~cm} / \mathrm{jam}$ dan $69.60 \mathrm{~cm} / \mathrm{jam}$. Media penghantar air yang digunakan adalah kain legacy yang memiliki nilai konduktivitas hidrolik sebesar $158.4 \mathrm{~cm} / \mathrm{jam}$. Pot terapung kemudian diterapkan pada bak percobaan dalam rumah tanaman. Penurunan muka air selama 41 hari masa tanam adalah 40,56 mm dengan volume total airnya adalah $0.082 \mathrm{~m}^{3}$. Nilai produktivitas air dan lahan tanaman selada pada media tanam $0 \%$ gambut, $30 \%$ gambut, $50 \%$ gambut, $70 \%$ gambut dan $100 \%$ gambut masing-masing adalah $1.37,1.63,1.06,1.57$ dan $1.42 \mathrm{~kg} / \mathrm{m}^{3}$ dan $1.29,1.25,1.06,0.8$ dan $0 \mathrm{~kg} / \mathrm{m}^{2}$.
\end{abstract}

Kata kunci: pot terapung, produktivitas lahan, produktivitas air irigasi bawah permukaan

\section{Introduction}

Wetlands are ecosystems that form, process and characters are controlled by water for an extended period for the development of vegetation and specially adapted organisms [1]. Indonesia is a country that has extensive peatland, which is an area of 18 million hectares [2] and 1 million hectares of which are in South Sumatra. Of total peatland area in South Sumatra, only 0.37 hectares are cultivated for rice once a year, while around 119 thousand are quite potential for rice cultivation but have not been utilised yet [3]. In addition to low soil fertility, another obstacle to agriculture in wetlands is water management related to the excessive nature of water during rainy season and drought during-dry season [4].

During flooding period, farmers usually leave their land inundated without any cultivation activities eventhough a floating farming system still could be applied to the flooded land. [5] had applied the system by planting kale on bamboo rafts combined with planting media treatments in which the soil was mixed with organic fertiliser made from water hyacinth and water nails. Vegetable cultivation could be carried out for several times in one flooding season so that it could increase farmers' income.

Furthermore, the cultivation of water spinach and other vegetables could be successfully done by using specifically designed floating media for wetlands. While the irrigation system applied to floating agriculture was subsurface irrigation. The subsurface irrigation system was carried out by giving water to plants by seeping water into the root area [6].

One of floating farming application is floating pot designed to float and seep water from below to 
the roots of plant using subsurface irrigation. Since the subsurface irrigation used is on open wetlands, it is necessary to know the amount of water used by plants during growth to obtain water productivity results. The productivity of floating pots in wetlands should also be evaluated as a comparison to conventional land productivity. Thus, this study was aimed to determine the productivity value of both water and floating pot in order to evaluate the affectivity of using floating pots for agriculture cultivation in wetlands.

\section{Material and Methods}

\subsection{Floating Pot}

Floating pot material was Styrofoam with density value of $0.015 \mathrm{~g} / \mathrm{cm}^{3}$. The subsurface irrigation was used for floating pot irrigation system by seeping water from below into the planting medium through the porous material. The type of porous material used provided an essential role in controlling the rate of irrigation water into the soil, especially in the characteristics of its hydraulic conductivity. Porous pot material was legacy fabric. The legacy fabric has a permeability value of 158.4 $\mathrm{cm} /$ hour. This value was higher than the planting media to be able to maintain water seepage from the subsurface to the planting media and maintain the moisture of the planting media. The dimensions of floating pots for vegetables in this study were $15 \mathrm{~cm}$ pot diameter and $17 \mathrm{~cm}$ pot height. Floating pot porous $17 \mathrm{~cm}$ long, $13 \mathrm{~cm}$ outside the pot and $4 \mathrm{~cm}$ inside the pot.

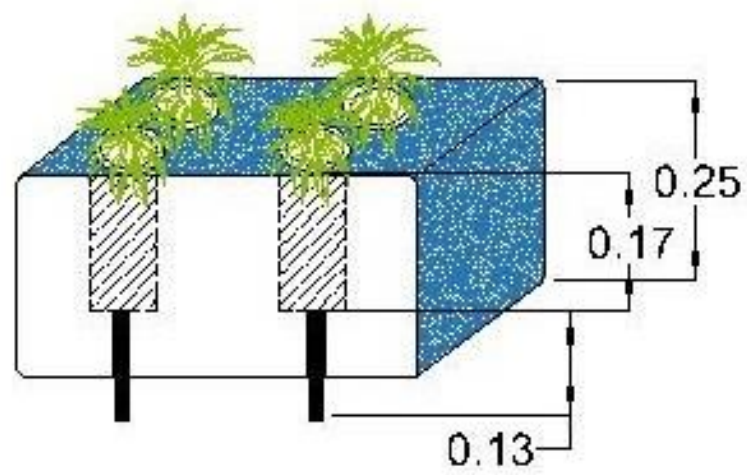

Figure 1. Floating Pot

\subsection{Planting Media}

This study used five types of planting media, which were planting media with a composition of mineral soil mixtures and 0, 30, 50, 70 and $100 \%$ peat soil $(\mathrm{G})$.

Table 1 The results of the analysis of the physical properties of soil samples

\begin{tabular}{|c|c|c|c|c|c|}
\hline \multirow{2}{*}{\multicolumn{2}{|c|}{ Parameters }} & \multicolumn{4}{|c|}{ Type of soil } \\
\hline & & $0 \% \mathrm{G}$ & $30 \% \mathrm{G}$ & $50 \% \mathrm{G}$ & $70 \% \mathrm{G}$ \\
\hline \multicolumn{2}{|c|}{ Bulk Density $(\mathrm{g} / \mathrm{cc})$} & 0.66 & 0.66 & 0.61 & 0.59 \\
\hline \multicolumn{2}{|c|}{ Particle Density (g/cc) } & 1.3 & 1.54 & 1.50 & 1.26 \\
\hline \multicolumn{2}{|c|}{ Soil porosity (\% volume) } & $57 \%$ & $53 \%$ & $57 \%$ & $59 \%$ \\
\hline \multicolumn{2}{|c|}{$\begin{array}{l}\text { Saturated soil hydraulic } \\
\text { conductivity }(\mathrm{cm} / \text { hour })\end{array}$} & 36.07 & 38.33 & 51.23 & 69.60 \\
\hline \multirow{4}{*}{$\begin{array}{l}\text { Water content } \\
\text { (\%volume) }\end{array}$} & $\mathrm{pF} 1$ & 52.00 & 41.10 & 40.70 & 36.80 \\
\hline & $\mathrm{pF} 2$ & 44.60 & 39.40 & 37.70 & 31.10 \\
\hline & $\mathrm{pF} 2.54$ & 40.50 & 34.00 & 32.00 & 27.80 \\
\hline & Pf4.2 & 35.40 & 26.80 & 23.70 & 20.70 \\
\hline
\end{tabular}

\subsection{Evapotranspiration}

The amount of water consumed by plants in floating pots on wetlands was obtained by calculating the value of evapotranspiration. The reference evapotranspiration value was calculated based on climatology data at the research location and the

$$
E T_{0}=\frac{0,408 \Delta(R n-G)+\gamma\left(\frac{900}{\mathrm{~T} * 273}\right) U_{2}(e s-e a)}{\Delta+\gamma\left(1+0,34 U_{2}\right)}
$$

$E T_{0}$ was a reference evapotranspiration $(\mathrm{mm}$ day-1), $R n$ was net radiation on the plant surface (MJ $\mathrm{m}^{-2}$ days $\left.^{-1}\right), G$ was the daily soil material flux density $\left(\approx 0 \mathrm{MJ} \mathrm{m}^{-2}\right.$ days $\left.^{-1}\right), U$ was average the speed of wind at the height of two meters (m seconds-1), Es was a
Dramaga Climatology Station belonging to the Meteorology, Climatology and Geophysics Agency (BMKG). Calculation of reference evapotranspiration following the FAO Penman-Monteith modification equation with the equation according to [7] was: saturated vapour pressure $(\mathrm{kPa}), E a$ was the actual vapour pressure $(\mathrm{kPa}), \Delta$ was the slope of the vapour pressure curve (kPa of-1), $\gamma$ was a psychometric constant $\left(\approx 0.0667 \mathrm{kPa}{ }^{\circ} \mathrm{f}-1\right)$, and $T$ was the average air temperature $\left({ }^{\circ} \mathrm{C}\right)$. 


\subsection{Land and Water Productivity of Lettuce}

Water consumption by plants in each planting medium was obtained by measuring the volume of water used by plants during growth. Water productivity of lettuce plants was formulated as follows:

$$
\text { Water Productivity }=\frac{\text { Lettuce production }(\mathrm{Kg})}{\text { Water volume of ETc }\left(\mathrm{m}^{3}\right)}
$$

\section{Results and Discussion}

\subsection{Decreasing Water Level and Water \\ Consumption Rate}

The decrease in the pond water level of floating farming systems and the rate of evapotranspiration is presented in Figure 3. The average water level reduction was $0.989 \mathrm{~mm} /$ day with 41 days total water loss of $40.56 \mathrm{~mm}$ or equal to $0.081 \mathrm{~m}^{3}$ for a tank area of $2 \mathrm{~m}$ and width $1 \mathrm{~m}$. Water level reduction was total evapotranspiration for all plants in five types of planting media. During the cultivation period, the water level from the surface of the pond continued to decline.

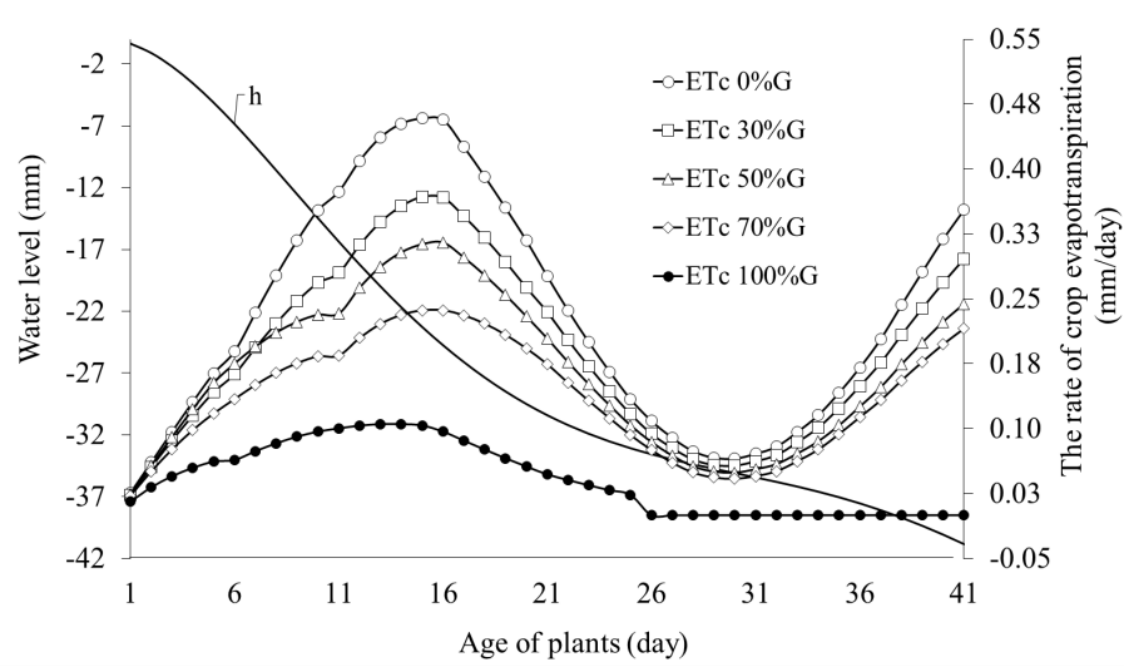

Figure 2. Relationship between water level reduction and evapotranspiration rate

The decrease in water level was interpolated using the 5 th order polynomial equation. The equation was based on the measurement of water

$$
h=a t^{5}-b t^{4}+c t^{3}-d t^{2}-e t-f
$$

$a=2.04487 \times 10^{-06}, b=0.00028297, c=$ $0.01353, d=0.24143, e=0.12326, f=0.00028, h$ was the water level measured by the sensor $(\mathrm{mm})$ and $t$ was the time (day). This 5-order polynomial equation was good enough to present a form of a tendency to decrease the water level based on CTD sensor measurements. This was based on the correlation value $\left(\mathrm{R}^{2}\right)$ obtained at 0.997 .

The negation of the derivative of 5 order polynomial equation was the rate of evapotranspiration of plants. The total value of the plant coefficient $(K c)$ was obtained from known plant evapotranspiration values and reference evapotranspiration. The rate of crop evapotranspiration in each planting media was the result of the decomposition of the total plant evapotranspiration rate. Decomposition of total $\mathrm{Kc}$ values into Kc units was optimized using the program solver in Microsoft Excel. Kc value analysis uses the level reduction data by CTD sensor measurements which tend to connect the trundling points. The 5th order polynomial equation was in the form of:

function of plant height and volumetric water content on the growing media every day so that the value of $K c$ obtained was different in each planting medium and every day. The total water consumption of plants after being analyzed during growth in the growing media of $0 \% \mathrm{G}, 30 \% \mathrm{G}, 50 \% \mathrm{G}, 70 \% \mathrm{G}$ and $100 \% \mathrm{G}$ was $9.41 \mathrm{~mm}, 7.76 \mathrm{~mm}, 6.82 \mathrm{~mm}, 5.60 \mathrm{~mm}$ and 1.69 $\mathrm{mm}$.

Figure 2 was also a scheme of the rate of evapotranspiration in lettuce plants in floating farming systems. The annual evapotranspiration value of plants was depended on the age of the plant every day. The evapotranspiration value of plants was still small and continues to increase in the early vegetative phase then decreases until the middle vegetative phase. During the final vegetative phase, evapotranspiration increased again until the final phase and was ready for harvest. At the beginning of plant growth, evaporation reached its maximum 
because the surface of the planting medium had not been covered by plant canopy. Evaporation would decrease in line with plant growth [8]. When plants grew into the final vegetative phase, plants needed more water than the initial vegetative phase, so that evapotranspiration increased again until the plants were ready to harvest.

\subsection{Lettuce Plant Production}

ojs.pps.unsri.ac.id

The results of the fresh and dry weight of lettuce production in each planting medium vary as presented in Table 2. The $0 \% \mathrm{G}$ planting media has the highest production tendency because the planting media without a mixture of peat soil can maintain greater water for plant needs.

Table 2: Production of lettuce plants

\begin{tabular}{ccccc}
\hline Types of planting media & $\begin{array}{c}\text { Fresh stovers weight } \\
\text { (grams) }\end{array}$ & $\begin{array}{c}\text { Dry stovers } \\
\text { weight (grams) }\end{array}$ & $\begin{array}{c}\text { Fresh root } \\
\text { weight (grams) }\end{array}$ & $\begin{array}{c}\text { Dry roots weight } \\
\text { (grams) }\end{array}$ \\
\hline $0 \% \mathrm{G}$ & 22.73 & 1.13 & 4.45 & 0.35 \\
$30 \% \mathrm{G}$ & 22.17 & 1.11 & 3.82 & 0.22 \\
$50 \% \mathrm{G}$ & 18.91 & 0.96 & 3.53 & 0.19 \\
$70 \% \mathrm{G}$ & 14.03 & 0.75 & 3.24 & 0.16 \\
\hline
\end{tabular}

\subsection{Water and Land Productivity of Lettuce Plants}

Based on the production of lettuce plants cultivated in floating pots in greenhouse by applying subsurface irrigation, the productivity of water and plant land was obtained from the ratio of wet weight in each planting medium. The total consumption of plant water during growth in the planting medium $0 \%$ $\mathrm{G}, 30 \% \mathrm{G}, 50 \% \mathrm{G}, 70 \% \mathrm{G}$ and $100 \% \mathrm{G}$ are 9.41 , 7.76, 6.82, 5.60 and $1.69 \mathrm{~mm}$. The results of the

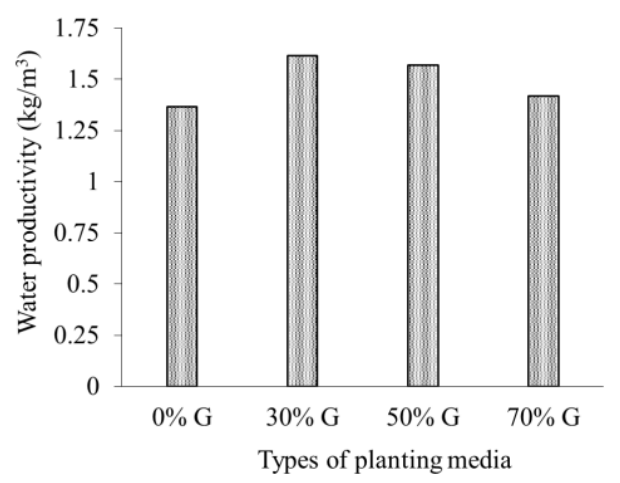

Figure 3. Water Productivity of Lettuce Plants

The results of calculation of lettuce crop productivity are presented in Figure 4. Productivity of plant land in planting media $0 \%, 30 \%, 50 \%$ and $70 \%$ of peat respectively are $1.29,1.25,1.06$ and 0.8 $\mathrm{kg} / \mathrm{m}^{2}$. The land productivity in this study was greater with the productivity of lettuce plants in the hydroponic system carried out by [10], which amounted to $1.27 \mathrm{~kg} / \mathrm{m}^{2}$.

\section{Conclusion}

Floating pots were applied to the experiment tank at the greenhouse with five types of planting media, which were mineral soil with a mixture of $0 \%$ peat, $30 \%$ peat, $50 \%$ peat, $70 \%$ peat and $100 \%$ peat. Water level decreased during the 41 day planting period was $40.56 \mathrm{~mm}$ with a total water volume of calculation of lettuce crop productivity are presented in Figure 3. Water productivity of plants in planting media $0 \%, 30 \%, 50 \%$ and $70 \%$ of peat respectively are $1.37,1.62,1.57$ and $1.42 \mathrm{~kg} / \mathrm{m}^{3}$. The planting media of $100 \%$ peat does not produce lettuce, so the water productivity was $0 \mathrm{~kg} / \mathrm{m}^{3}$. The productivity of lettuce in this study was greater than the productivity of drip wet irrigation water with limited water supply [9] with a value of $0.61 \mathrm{~kg} / \mathrm{m}^{3}$.

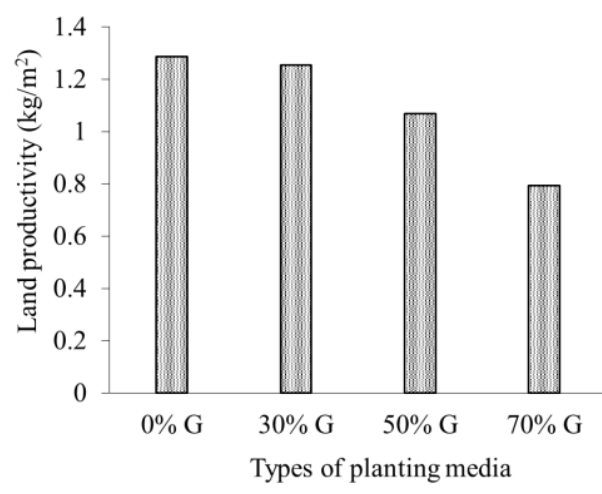

Figure 4. Land Productivity of Lettuce Plants

$0.081 \mathrm{~m}^{3}$. The water productivity value of lettuce plants in the planting media of $0 \%-100 \%$ peat respectively were $1.37,1.62,1.57,1.42$ and $0 \mathrm{~kg} /$ $\mathrm{m}^{3}$. The value of land productivity of lettuce in the planting media of $0 \%-100 \%$ peat was $1.29,1.25$, $1.06,0.8$ and $0 \mathrm{~kg} / \mathrm{m}^{2}$, respectively. Lettuce cultivation on floating pots could be applied to optimize wetlands use for agriculture because productivity value of water and land could be greater than conventional lettuce cultivation.

\section{References}

[1] J.O. Rieley, A.A. Ahmad-Shah and M.A. Brady. "The Extern and Nature of Tropical Peat Swamps" in Maltby E et al., editor. Proc. Of a Workshop on Integrated Planning and http://dx.doi.org/10.22135/sje.2019.4.2.104-108 107 
Management of Tropical Lowland Peatlands, IUCN, pp 17-54, 1996.

[2] S. Najiyati, L. Muslihat and I.N.N. Suryadiputra. "Panduan Pengelolaan Lahan Gambut untuk Pertanian Berkelanjutan. Proyek Climate Change, Forests and Peatlands in Indonesia." Bogor: Wetlands International - Indonesia Progamme. 2005.

[3] Waluyo and Supartowo. "Peluang dan Kendala Pengembangan Pertanian pada Agroekosistem Rawa Lebak: Kasus Desa Kota Daro II di Kecamatan Rantau Panjang Kabupaten Ogan Ilir Sumatera Selatan." in Proc. Prosiding Seminar Nasional Lahan Suboptimal, 2014, pp 704-713.

[4] B. Bakri, M.S. Imanudin and S.M. Bernas. "Water Retention Option of Drainage System for Dry Season Corn Cultivation at Tidal Lowland Area." Agrivita, vol 37, issue 3, pp 237, 2015.

[5] S.M. Bernas, A. Pohan, S.N.A. Fitri and E. "Kurniawan.. Model Pertanian Terapung dari Bambu untuk Budidaya Kangkung Darat (Ipomoea reptans Poir.) di Lahan Rawa." Jurnal Lahan Suboptimal, vol 1, pp 178-185, 2012.
[6] Kang S. and Zhang J. "Controlled alternate partial root-zone irrigation: its physiological consequences and impact on water use efficiency." Journal of experimental botany, vol 55, issue 407, pp 2437-2446, 2004.

[7] R.G. Allen, L.S. Pereira, D. Raes, M. Smith. Crop Evapotranspiration - Guidelines for Computing Crop Water Requirements. Rome (IT): Food and Agriculture Organization of the United Nations (FAO), 1998.

[8] Hermantoro and Pusposutarjo. "Pemodelan Pertumbuhan dan Pemakaian Air Tanaman Palawija di Lahan Kering." Buletin Keteknikan Pertanian, vol 14, issue 2, pp 139-149, 2000.

[9] S. Contreras, A.B. Mark and T. David. "Restricted Water Availability During Lettuce Seed Production Decreases Seed Yield per Plant but Increases Seed Size and Water Productivity." Hort Science, vol 43, issue 3, pp 837-844, 2008.

[10] R.P. Prawoto and J.G. Kartika. "Pengelolaan Aspek Produksi dan Pasca Panen Sayuran Daun Secara Aeroponik dan Hidroponik: Studi Kasus Lembang, Bandung". Bul. Agrohorti, vol 4, issue 1, pp 9-19, 2016. 